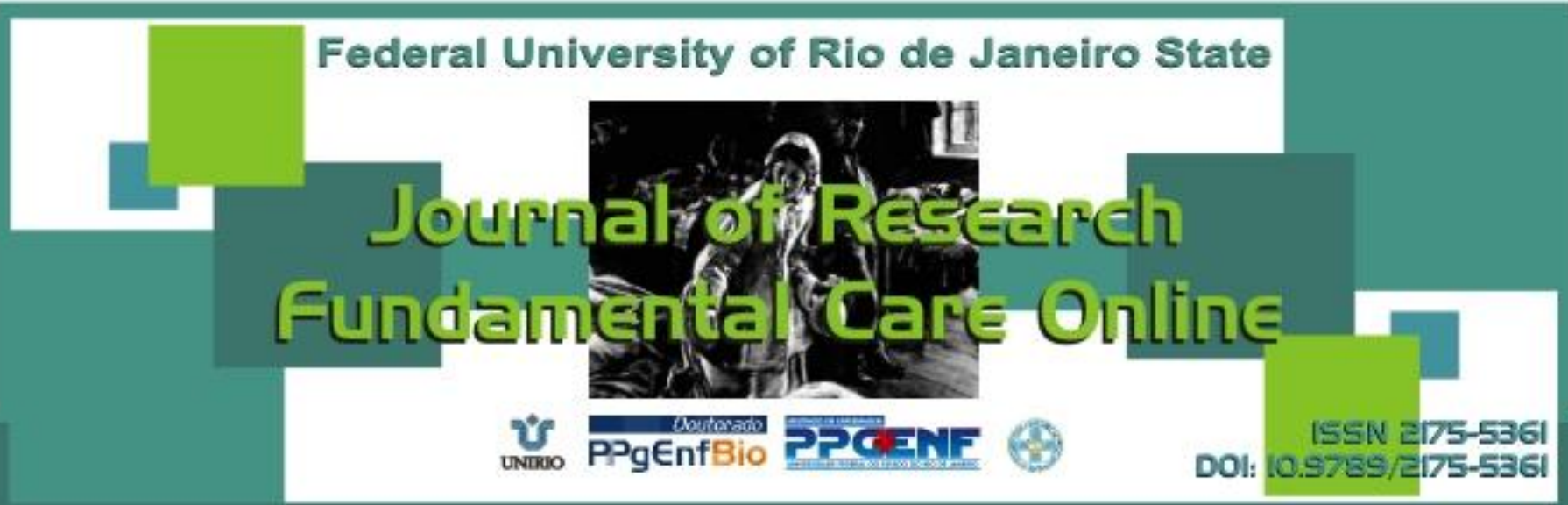

INTEGRATIVE REVIEW OF THE LITERATURE

\title{
Care to children with cleft lip-palate: an integrative review
}

Cuidados à criança com fissura labiopalatina: uma revisão integrativa

Atención a niños con labiopalatino hendido: una revisión integradora

Kelen Cristina Ramos dos Santos ${ }^{1}$, Marcia Luciane da Silva Bohn ${ }^{2}$, Giordana de Cássia Pinheiro da Motta $^{3}$, Eveline Franco da Silva ${ }^{4}$, Elisiane Lorenzini ${ }^{5}$

ABSTRACT

Objective: To analyze the scientific production that addresses the care to children with cleft lip-palate. Method: Bibliographical research of integrative literature review type. The searches were conducted in BDEnf, LILACS and SciELO databases. Results: The study included 11 articles that met the inclusion criteria, published between 2000 and 2011. As for the knowledge area of the principal author of each study, there were contained three articles of dentistry, medicine, three, three of nursing and two of nutrition. The studies addressed nutritional care, dental care, and multidisciplinary team approach for mothers, and protocols for postoperative care. Conclusion: The nursing staff, especially nurses, have an important role in assisting the child with cleft lip-palate. It emphasizes the integration of the multidisciplinary team to provide holistic care and improvements in quality of life of children with cleft lip-palate. Descriptors: Cleft palate, Cleft lip, Infant care, Child care.

RESUMO

Objetivo: Analisar a produção científica que aborda os cuidados à criança com fissura labiopalatina. Método: Pesquisa bibliográfica do tipo revisão integrativa da literatura. As buscas foram realizadas nas bases de dados BDEnf, LILACS e SciELO. Resultados: Foram analisados 11 artigos que atenderam aos critérios de inclusão, publicados de 2000 a 2011. Quanto à área de conhecimento do principal autor de cada estudo, compreenderam três artigos da odontologia, três da medicina, três da enfermagem e dois da nutrição. Os estudos abordaram cuidados alimentares, odontológicos, equipe multiprofissional, abordagem às mães, pós-operatório e protocolos de atendimento. Conclusão: A equipe de enfermagem e, sobretudo o enfermeiro, tem papel relevante na assistência à criança com fissura labiopalatina. Ressalta-se a integração da equipe multidisciplinar e a visão holística do cuidado a fim de proporcionar melhorias na qualidade de vida das crianças portadoras de fissura labiopalatina. Descritores: Fissura palatina, Fenda labial, Cuidado do lactente, Cuidado da criança.

\section{RESUMEN}

Objetivo: Analizar la producción científica que cubre la atención a los niños con labio-palatino hendido. Método: Investigación bibliográfica de tipo revisión de literatura Integrativa. Las búsquedas se realizaron en las bases de datos BDEnf, LILACS y SciELO. Resultados: El estudio incluyó 11 artículos que cumplían los criterios de inclusión, publicados desde 2000 hasta 2011. En cuanto al área de conocimiento del autor principal de cada estudio, contenía tres artículos de la odontología, la medicina tres, tres de enfermería y dos de nutrición. Estos estudios han abordado la atención nutricional, odontológica, equipo multidisciplinario, el enfoque para las madres, y los protocolos de cuidados postoperatorios. Conclusión: El equipo de enfermería y las enfermeras en particular, tienen un papel importante en asistir al niño con labio-palatino hendido. Se destaca la integración del equipo multidisciplinario y el cuidado integral para proporcionar mejoras en la calidad de vida de los niños con labio-palatino hendido. Descriptores: Fisura del palatino, Hendidura labial, Cuidado del lactante, Cuidado del niño.

${ }^{1}$ Nurse from the Federal University of Rio Grande do Sul (UFRGS). Member of the study group to health care in the stages of life (CEVIDA/UFRGS). E-mail: kelencrs@gmail.com. ${ }^{2}$ Nurse from UFRGS. Member of the Group of studies in collective health (GESC/UFRGS). E-mail: malumarchand@ibest.com.br. ${ }^{3}$ Master's degree in Nursing from UFRGS. Nursing specialist in neonatology. Nurse of inpatient Neonatal Unit of the Hospital de Clínicas de Porto Alegre. Substitute teacher of the Department of maternal and child Nursing of UFGRS. Member of the group for the study of women's health and the baby (GEMBE/UFRGS). E-mail: giordanamotta@yahoo.com.br. ${ }^{4}$ Master's degree in nursing from UFRGS. Nurse Midwife. College faculty member at our Lady of Fatima. Member of the group for the study of women's health and the baby (GEMBE/UFRGS). E-mail: evelinefranco@yahoo.com.br. ${ }^{5}$ Master in health sciences by University Foundation of Cardiology of Rio Grande do Sul. Nursing management specialist. Faculty member of the University FEEVALE and College Nossa Senhora de Fátima. Member of the nucleus of studies on nursing Management (DENY/UFRGS). E-mail: elisilorenzini@gmail.com. 


\section{INTRODUCTION}

mong the developmental anomalies, cleft lip-palate (CLP) is one of the most common craniofacial malformations. ${ }^{1}$ The prevalence varies according to geographical location. In Brazil, the occurrence of an affected child is every 650 live births. ${ }^{2}$ According to information extracted from DATASUL the Ministry of Health, 1425 cases were reported in Brazil in 2009, with 98 of them in the state of Rio Grande do Sul. ${ }^{3}$

The cleft lip and palate (CLP) is characterized by a change in the formation of the face that occurs around the $4^{\text {th }}$ to the $12^{\text {th }}$ week of intrauterine life. The etiology is considered multifactorial, ${ }^{4}$ although recent studies demonstrate the influence of genetic factor in the emergence of this malformation. ${ }^{5} \mathrm{~A}$ cleft lip $(\mathrm{CL})$ is due to hypoplasia of the medial nasal process and maxillary between four and seven weeks of embryonic life. Already cleft palate (CP) occurs as a result of hypoplasia of the maxillary palatal process, between seven and 12 weeks. ${ }^{4-5}$

According to the involvement of anatomical structures are classified as CLP, CL and CP. ${ }^{6}$ Studies show higher occurrence of CLP then by CL and CP. ${ }^{1,6} A c c o r d i n g$ to some studies, more than half of affected children are male and most common type in this genre is CLP. However, the CP in isolation occurs more frequently in females. ${ }^{1,6}$ The CLP can occur alone or in association with other anomalies, constituting the syndromes. Children with nonsyndromic lip-palate lesions develop as the general population, within the normal range. ${ }^{7}$ In general, reconstructive surgery is beneficial, improving the aesthetics and function of the child. However, your statement depends on the patient's nutritional status and decisions of the multidisciplinary team.

Although not reduce life expectancy, CLP causes significant functional changes, social, emotional and aesthetic that require multidisciplinary care. ${ }^{1}$ In this scenario, the nurse has an important space to exercise humanized and contribute to reducing the emotional impact, acting as a figure of connection between the team and family. ${ }^{8} \mathrm{Children}$ with CLP require personalized care to meet their needs, ensuring survival and quality of life.

Given the importance of caring for the proper growth and development, this integrative review is to analyze the scientific productions that address child care with CLP. 


\section{METHODOLOGY}

It is a literature from the perspective of an integrative literature review. This method allows the incorporation of research evidence into clinical practice in order to gather and synthesize research findings on a specific topic under study, in a systematic and orderly. ${ }^{9}$

To develop this study went through the following steps: setting the goal of integrative review, establishing criteria for inclusion and exclusion of articles; definition of the information to be extracted from selected articles, analysis of results, discussion and presentation of the results and the last step constitutes the presentation of the review. ${ }^{10}$

To guide this research formulated the question: What scientific production approach on the care of children with cleft lip-palate?

There was defined as a source of search data bases: BDEnf, SciELO and LILACS. These databases as references in production in nursing and health care, in which he used the following descriptors: infant $O R$ child $A N D$ Cleft palate $O R$ cleft lip $O R$.

Initially , to study selection of this integrative review were defined inclusion criteria: only articles from studies conducted in Brazil, in Portuguese language, full text available, which contained information on care of children with cleft lip and palate. Thus were excluded theses and dissertations, international studies, scientific productions without abstracts in databases and repetitions present in different databases. The search was conducted by the productions in the months of September and October 2011.For the examination and synthesis of the selected articles there was built a summary table, which included the aspects considered relevant: year of publication, journal, goal; considerations and results / conclusions; area of concentration of the authors, etc.

232 publications were identified in the databases. After thorough analysis, 11 articles met the inclusion criteria, constituting the study sample.

The data used in this study were properly referenced with the identification of the authors and other research sources, respecting the ethics regarding the use of content and quote texts of works consulted. In order to maintain the blind review, items were coded (A01, A02, ... A11), identifying the authors only after the analysis. 


\section{RESULTS AND DISCUSSION}

The sample consisted in 11 journal articles (Table 1) from different areas of knowledge in the health sciences. The database with the largest number of articles on this topic was the LILACS, eight publications. The highest incidence of publications occurred in 2008 and 2009, with three published articles. The State of São Paulo (SP) was the primary site of origin, with $54,5 \%$ of the total number of publications in the sample. As for the area of knowledge of the principal author of each study, comprise three of dentistry, medicine three, three and two nursing nutrition, reflecting the trend of multidisciplinary care in the selected theme.

Table 1 - Presentation of the studies according to code, title, year and database. Porto Alegre, RS, 2011.

\begin{tabular}{|c|c|c|c|}
\hline COD & & & DATABAS \\
\hline A01 & $\begin{array}{l}\text { Retrospective study of postoperative complications in } \\
\text { surgery primary lip and palate }\end{array}$ & 2008 & BDENF \\
\hline A02 & $\begin{array}{l}\text { Anthropometry and risk factors in newborns with facial } \\
\text { clefts }\end{array}$ & 2004 & SCIELO \\
\hline A03 & Listening mothers of patients with oral clefts & 2011 & SCIELO \\
\hline A04 & $\begin{array}{l}\text { Feeding the child with cleft lip and/or palate: a } \\
\text { bibliographical study }\end{array}$ & 2000 & LILACS \\
\hline A05 & $\begin{array}{l}\text { Infant carrier power of lip injury-palatal: breastfeeding } \\
\text { and food introduction }\end{array}$ & 2001 & LILACS \\
\hline A06 & $\begin{array}{l}\text { Dental aspects of fissures lip-palate and guidelines for } \\
\text { basic care }\end{array}$ & 2008 & LILACS \\
\hline A07 & $\begin{array}{l}\text { Comparative and evolutionary evaluation of protocols } \\
\text { of care of cleft patients }\end{array}$ & 2010 & LILACS \\
\hline A08 & $\begin{array}{l}\text { Evaluation of babies with cleft lip and palate in } \\
\text { relation to oral hygiene }\end{array}$ & 2009 & LILACS \\
\hline A09 & $\begin{array}{l}\text { Nutritional status and practice of breastfeeding of } \\
\text { children with caries fissures of Cascavel/Paraná }\end{array}$ & 2009 & LILACS \\
\hline $\mathrm{A} 10$ & $\begin{array}{l}\text { Cleft lip and palate: study on the population assisted } \\
\text { by a referral service in the State of Minas Gerais }\end{array}$ & 2009 & LILACS \\
\hline A11 & $\begin{array}{l}\text { Social representations of mothers of children with cleft } \\
\text { lip and palate about breastfeeding }\end{array}$ & 2008 & LILACS \\
\hline
\end{tabular}

In general, the topics addressed in scientific productions were: nutrition, dental aspects, and nutritional knowledge of mothers, postoperative complications and protocols. Regarding the care to be provided to children with CLP, we highlight the nutritional care and oral hygiene in most studies analyzed. Preparation of the multidisciplinary team, health status preoperatively and postoperatively of corrective surgeries comparative evaluation of protocols and appropriate approach to the care mothers were also reported, but at a lower prevalence. 
For being a condition partially known by society, it is understood that it is necessary for practitioners provide detailed guidance to the family about the care of a child with CLP. Study ${ }^{11}$ concluded that early weaning was high among the children investigated, and among 11 mothers interviewed, four of them breastfed for up to one month and four never breastfed. In this sense, difficulty in feeding the newborn depends on the complexity of the crack, which may result in inadequate suction for lack of intraoral pressure, prolonged and regurgitation. ${ }^{12}$ Nevertheless, breastfeeding should be encouraged, ${ }^{11-3}$ since the child with CLP presents the sucking reflex preserved. To avoid complications, some guidelines are recommended, such as: keeping the child in semi-sitting position by offering food to prevent suction; take breaks during the feeding to promote belching; oral muscles to exercise, providing stimuli on the side of the fissure through contact with the nipple or bottle, put the child in the lateral position after feeding to reduce the risk of choking. ${ }^{12}$

Faced with the impossibility of breastfeeding, it is recommended to express milk and offer it to the child by bottle or cup / glass as the best alternative, simple and low cost. ${ }^{12}$ The use of cup feeding the child prevents the functional problems allow the exercise facial muscle the effort to seek the milk with the tongue. Bottle-feeding increases the risk of contamination and developmental disorders of the oral cavity. ${ }^{14}$ The gastric tube is discouraged by harming the reflexes of sucking and swallowing. In the choice of bottle nipple adequate attention should be paid to some characteristics such as length, flexibility, hole size and the position adopted in the oral cavity. ${ }^{12}$ Nozzle orifice of the bottle should be small due to risk of choking and aspiration. ${ }^{14}$

Oral hygiene is an important caution adopted in preventing dental complications and should be enhanced in children with CLP. ${ }^{15-6} \mathrm{~A}$ study that investigated the prevalence of caries related not performing oral hygiene concluded that the lack of cleanliness was not a factor in the manifestation of caries increment. However, the guidelines for dental care must persist. ${ }^{17}$ Ideally, parents should be counseled about the early dental care. Always after feeding, oral and nasal cavities need to be sanitized with diaper or gauze soaked in saline or filtered water. Difficulties in cleaning the oral cavity may predispose the appearance of tooth decay and periodontal diseases. Therefore, it is essential to the attention of health professionals in the care and prevention of odontological complications. ${ }^{15}$ Thus, due to the fact that nursing staff interact daily with the patient and family, these professionals can provide guidance on oral hygiene at runtime and demonstration of first aid, encouraging parents to exercise the necessary care for the child.

For monitoring of children with CLP, the multidisciplinary team consists of professionals who specialize in otolaryngology, dentistry, speech therapy, psychology, clinical medicine, physiotherapy, nursing, nutrition, plastic surgery, social work and anesthesia, as well as family care. ${ }^{17} \mathrm{~A}$ multidisciplinary approach participates in the necessary support to overcome the challenges, ${ }^{16}$ generating greater supply and improving access to health services. A comprehensive health promotion and facilitation of access contribute positively in the development of the child. ${ }^{18}$ In addition, knowledge of or facial malformations and the approach to be adopted by nurses and other team members are important in guiding parents and answer questions about care and treatment.

Study evaluating risk factors and anthropometry in newborns with facial clefts ${ }^{17}$ showed a significant association between the presence of malformations in the family and 
the occurrence of $\mathrm{CL}$, and an important correlation between maternal education and the occurrence of facial clefts, indicating the importance care education to pregnant women. In this sense, communicate properly diagnosed and, where possible, early, helps to minimize the suffering of parents and promotes mother-child relationship. ${ }^{11}$ The preparation of the team and the type of approach are essential to the development of the bond. Furthermore, listening to mothers and knowledge of the beliefs and reality family contribute to the optimization of care. ${ }^{19}$

For performing corrective surgeries, it is necessary that the child does not present diseases and have adequate nutritional status. ${ }^{20}$ In a study with 484 patients who underwent primary lip and palate, $58 \%$ had at least one complication in the recovery room after anesthesia. The most common complications encountered were pain, decreased oxygen saturation, tachycardia. ${ }^{2} \mathrm{~A}$ recent study, published in 2010, which conducted benchmarking and evolving protocols of care of cleft patients, concluded that, using treatment protocols, standardization of treatment results in decreased complications. ${ }^{21}$. In preoperatively and postoperatively of corrective surgeries highlights the care of the nursing staff who can contribute to the detection of risk factors, identification and mitigation of complications.

\section{CONCLUSION}

For aesthetic factors involved, social and functional CLP requires multidisciplinary performance from the perspective of care to assist the child and his family to meet the challenges of this condition.

This integrative review identified the scientific publications that address the care to be provided to children with CLP. Despite the scarcity of current productions on the subject specifically in the selected sample it was possible to find the care that encompasses the individual and family of these children, as well as aspects of multidisciplinary care. Were identified care about food, oral hygiene, preparation of staff, health conditions before and after corrective surgery, benchmarking of clinical protocols and appropriate approach to the mothers. The issues discussed are relevant for allowing the promotion of the prevention of complications in children with CLP.

In this context, the nursing staff and especially the nurse has an important role in assisting the child with CLP for acting in direct care, acting as a figure of connection between the team and the family. Through guidance and support qualified nurses to contribute to the encouragement of parents and families in child care. We emphasize the importance of integrating multidisciplinary and holistic care to provide improvements in the quality of life of children with CLP.

Finally, there is the need for more studies that portray the care prioritized this specific population. 


\section{REFERENCES}

1. Paranaíba LMR, Miranda RT, Ribeiro LA, Barros LM, Martelli-Júnior H. Frequency of congenital craniofacial malformations in a Brazilian Reference Center. Rev Bras Epidemiol. 2011;14(1):151-60.

2. Biazon J, Peniche ACG. Estudo retrospectivo das complicações pós-operatórias em cirurgia primária de lábio e palato. Rev Esc Enferm USP. 2008;42(3):519-25.

3. Ministério da Saúde (BR). Departamento de Informática do SUS - DATASUS [Internet]. Brasília: Ministério da Saúde [cited 2012 feb 11]. Sistema de Informações sobre Nascidos Vivos - SINASC. Available from: http://tabnet.datasus.gov.br/CGI/tabcgi.exe?sinasc/cnv/nvuf.def.

4. Kot M, Kruk-Jeromini J. Analysis of family incidence of cleft lip and/or palate. Med Sci Monit. 2007;13(5):CR231-34.

5. Martelli DR, Bonan PRF, Soares MC, Paranaíba LR, Martelli-Júnior H. Analysis of familial incidence of non-syndromic cleft lip and palate in a Brazilian population. Med Oral Patol Oral Cir Bucal. 2010 nov 1;15(6):e898-901.

6. Freitas AB, Carvalho CA, Martelli DRB, Barros LM, Bonan PRF, Martelli-Júnior H. Fissuras lábio-palatinas: estudo sobre a população assistida por um serviço de referência no Estado de Minas Gerais. Arq Odontol. 2009 abr/jun;45(5):107-12.

7. Jaruratanasirikul S, Chichareon V, Pattanapreechawong N, Sangsupavanich P. Cleft lip and/or palate: 10 years experience at a pediatric cleft center in Southern Thailand. Cleft Palate Craniofac J. 2008 nov;45(6):597-602.

8. Fontoura FC, Fontenele FC, Balbino AC, Cardoso MV. Newborn with congenital anomaly: a focus on nursing diagnoses. Rev Enferm UFPE On Line [Internet]. 2012 oct [cited 20 dec 2012];6(10):2387-95. Available from: http://www.revista.ufpe.br/revistaenfermagem/index.php/revista/article/view/3225/pdf_ 1527.

9. Mendes KDS, Silveira RCCP, Galvão CM. Revisão integrativa: método de pesquisa para a incorporação de evidências na saúde e na enfermagem. Texto \& Contexto Enferm. 2008 out/dez;17(4):758-64.

10. Souza MT, Silva MD, Carvalho R. Revisão integrativa: o que é e como fazer. Einstein. 2010;8(1):102-6.

11. Silveira JLGC, Weise CM. Representações sociais de mães de crianças portadoras de fissuras labiopalatinas sobre aleitamento. Pesq Bras Odontoped Clin Integr. 2008 mai/ago;8(2):215-21.

12. Araruna RC, Vendrúscolo DMS. Alimentação da criança com fissura de lábio e/ou palato um estudo bibliográfico. Rev Lat Am Enfermagem. 2000 abr;8(2):99-105.

13. Pini JG, Peres SPBA. Alimentação do lactente portador de lesão lábio-palatal: aleitamento e introdução alimentar. Rev Nutr. 2001 set/dez;14(3):195-9. 
14. Ministério da Saúde (BR). Secretaria de Vigilância à Saúde. Secretaria de Atenção à Saúde. Guia prático de preparo de alimentos para crianças menores de 12 meses que não podem ser amamentadas. Brasília: Ministério da Saúde; 2004.

15. Roda SR, Lopes VLGS. Aspectos odontológicos das fendas labiopalatinas e orientações para cuidados básicos. Rev Cienc Méd. $2008 \mathrm{mar} / \mathrm{abr}$ [cited 12 feb 2012];17(2):95-103. Available from: http://www.puccampinas.edu.br/404.aspx?urlFrom=centros/ccv/revcienciasmedicas/artigos/v17n2a4.pdf. 16. Moura AM, Andre M, Faraj JORA, Dias RB. Avaliação de bebês portadores de fissura labiopalatina em relação à higiene oral. Rev Odont [Internet]. 2009 [cited 11 feb 2012];17(34):64-8. Available from: https://www.metodista.br/revistas/revistasmetodista/index.php/01/article.

17. Cunha ECM, Fontana R, Fontana T, Silva WR, Moreira QVP, Garcias GL, et al. Antropometria e fatores de risco em recém-nascidos com fendas faciais. Rev Bras Epidemiol. 2004;7(4):417-22.

18. Furtado, MCC, Mello DF, Parada CMGL, Pinto IC, Reis MCG, Scochi CGS. Avaliação da atenção ao recém-nascido na articulação entre maternidade e rede básica de saúde. Rev Eletr Enf [Internet]. 2010 [cited 2011 dec 29];12(4):640-6. Available from: http://revistas.ufg.br/index.php/fen/article/view/7625/8467.

19. Vanz AP, Ribeiro NRR. Escutando as mães de portadores de fissuras orais. Rev Esc Enferm USP. 2011;45(3):596-602.

20. Piccin S, Machado AD, Bleil RT. Estado nutricional e prática de aleitamento materno de crianças portadoras de fissuras labiopalatais de Cascavel/Paraná. Nutrire: Rev Soc Bras Alim Nutr. 2009 dez;34(3):71-83.

21. Alonso N, Tanikawa DYS, Junior JEL, Ferreira MC. Avaliação comparativa e evolutiva dos protocolos de atendimento dos pacientes fissurados. Rev Bras Cir Plást. 2010;25(3):434-8. 